\title{
Evaluation on Environmental Resource Value of Artificial Seabuckthorn Forest in Sandstone Area during 1999-2008
}

\author{
Jianzhong Hu
}

China National Administration Center for Seabuckthorn Development, Beijing, China.

Email: bfuswc@163.com

Received October $9^{\text {th }}, 2013$; revised November $10^{\text {th }}, 2013$; accepted November $16^{\text {th }}, 2013$

Copyright (C) 2013 Jianzhong Hu. This is an open access article distributed under the Creative Commons Attribution License, which permits unrestricted use, distribution, and reproduction in any medium, provided the original work is properly cited.

\begin{abstract}
China Seabuckthorn Ecological Project has been implemented for a decade (from 1999 to 2008) with an increasing seabuckthorn area of $1642.83 \mathrm{~km}^{2}$ in the Sandstone Areas of Shanxi, Shaanxi and Inner Mongolia-the most serious soil erosion area in China. The vast artificial seabuckthorn forest's value in environmental resource is assessed via 7 indicators on first-level, 15 indicators on secondary level and 35 indicators on third level in this research. As of 2008, the seabuckthorn environmental resource value is 10.017 billion RMB Yuan, which equals to 37.1 times of the project's total investment of 0.27 billion RMB Yuan. It is proposed in this research that the external economical values such as soil and water conservation, windbreak and sand-fixation can be realized through relative national policies and taxes. Carbon-fixation and oxygen-producing value can be achieved through the international carbon trade.
\end{abstract}

Keywords: Seabuckthorn; Ecological Project; Environmental Resource Value; Evaluation; Sandstone Areas; China

\section{Introduction}

The Sandstone Area in the upper and middle reaches of the Yellow River in China, with ravines everywhere, bedrock exposed, sparse vegetation and concentrated rainfall, has the most serious soil erosion problem in China. In the 1980s, experimental planting of seabuckthorn (Hippophae rhamnoides) was carried out in this area. The result showed that seabuckthorn had the advantages of quick recovery on the bare rocks, low cost, high developing value, etc. Hereby, "Seabuckthorn Project in the Sandstone Areas of Shanxi, Shaanxi and Inner Mongolia” formally started after many discussions and the approval by the Ministry of Water Resources, P. R. China. The project lasted for 10 years from 1999 to 2008 . When the project ended in 2008, it passed the inspection of the Ministry of Water Resources successfully. Later, the research findings and achievements came out one after another [1]. This paper makes estimation about the project's environmental resource value in order to make further scientific estimation in post-project stage. It is believed that timely review will provide useful reference to similar projects or areas in the future.

\section{Indicator Assessment System Construction}

The Construction of Indicator Assessment System meets the requirements of systematicness, hierarchy, simplicity and operability. The system is built up on the basis of access to a large number of on-site researches and domestic and foreign literatures with many experts' suggestions taken into consideration. They are:

Target: seabuckthorn environmental resource value in the Sandstone Areas (A)

Function: seven indicators-soil conservation (B1), water conservation (B2), windbreak and sand-fixation (B3), biological diversity (B4), carbon fixation and oxygen producing (B5), environment cleaning (B6) and landscape (B7)

Criterion: 15 indicators (Table 1)

Index: 35 indicators (Table 1)

\section{Methodology of Assessment}

Generally speaking, the known ecological function (or benefits) is transformed into ecological function (or benefits) in economic measurement by some appropriate 
Table 1. Environmental resource assessment system of seabuckthorn ecological project in Sandstone Area.

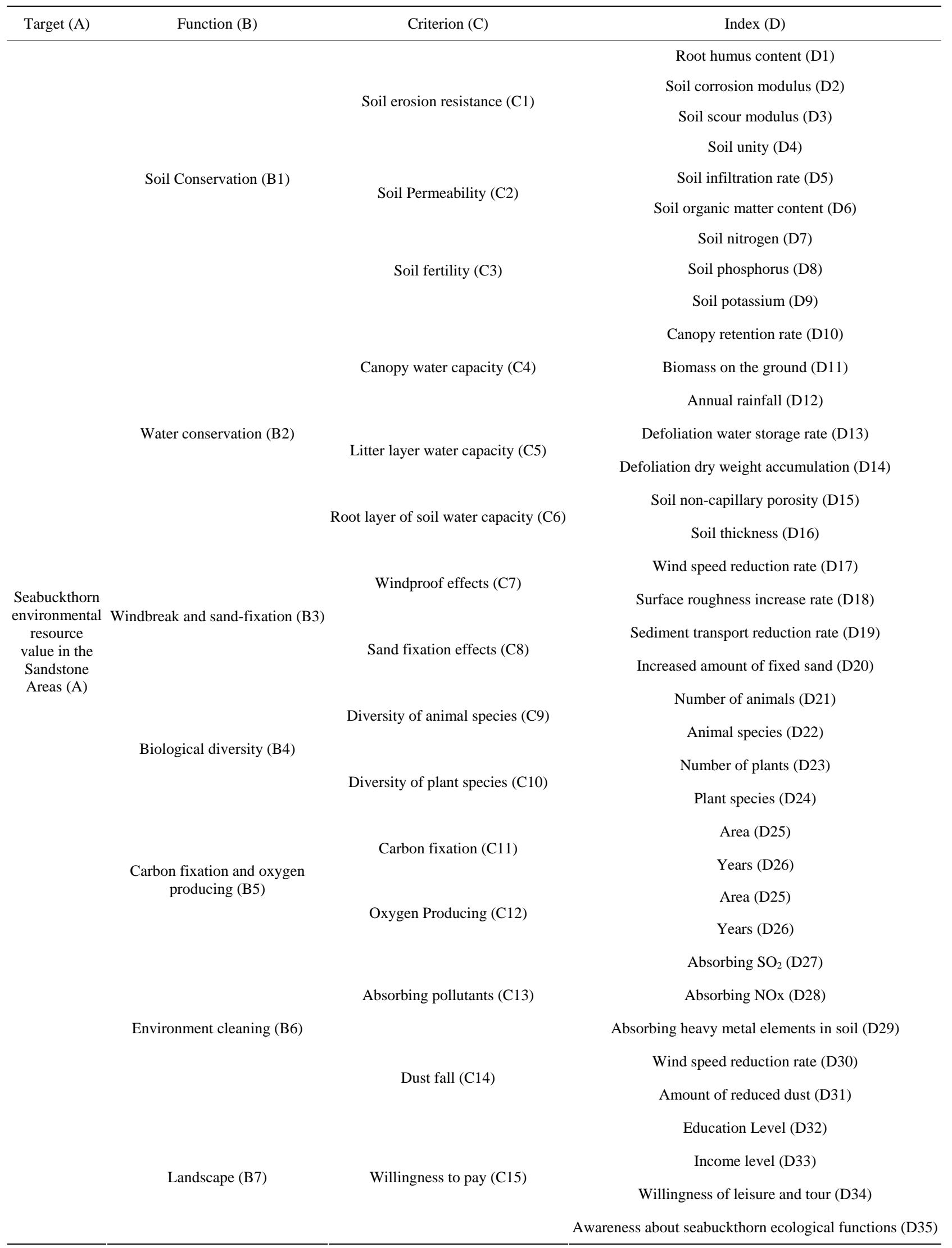


economic transformation parameters via value assessment [2]. Economic parameter should be set with high operability and can be adjusted according to regional characteristics and local price index.

By using the Market Price method or Market-Replace Price method, the assessment of seabuckthorn environmental resource value is made objective and impartial, with little arbitrariness and subjectivity.

\subsection{Soil Conservation}

Seabuckthorn forest's soil conservation value is assessed from soil erosion reduction, sediment reduction, soil fertility loss reduction and soil nurturing (B1).

\subsection{Water Conservation}

The total seabuckthorn water content can be calculated from 3 parts-forest canopy, litter layer and root soil layer. Then the seabuckthorn water conservation value can be calculated through Price-Replace method by transforming the probably created economic value (B2).

\subsection{Windbreak and Sand-Fixation}

The fixed sand amount can be translated into area of land in desertification. The cost of its recovery to agricultural land equals the seabuckthorn's value in Windbreak and sand-fixation (B3).

\subsection{Biological Diversity}

The quantitative value per unit area can be defined with Shannon-Wiener Index [3,4]. When Multiplied by the seabuckthorn forest area, the Biological diversity value comes out (B4).

\subsection{Carbon Fixation and Oxygen Producing}

Seabuckthorn Carbon fixation calculation should be done in two parts-seabuckthorn canopy and soil layer. According to Swiss Carbon tax rate, the price of Carbon fixation is \$150/t (i.e. $¥ 1200 / t$ ); According to the price released on the website of the Ministry of Health, P. R. China in 2007 Spring, the average price of oxygen is $¥$ $1000 /$ t. Their total value makes the seabuckthorn value of Carbon fixation and oxygen producing (B5).

\subsection{Environment Cleaning}

Here we take $\mathrm{SO}_{2}$ and dust reduction as an example.The cost of controlling the same amount of $\mathrm{SO}_{2}$ and dust equals toseabuckthorn environment cleaning value (B6).

\subsection{Landscape}

When Market Price method and Market-Replace Price method are beyond number, Contingent Evaluation Method [5-7] provides us a way to assess seabuckthorn Landscape value through the investigation of public's primarily willingness to pay for environmental goods or services (B7).

\section{Results and Further Discussion}

Table 2 shows the planted and preserved area of artificial seabuckthorn forest in the Sandstone Area project-implementing Counties each year from 1999 to 2008. It is found that after 10-year seabuckthorn planting, in the Sandstone area, the seabuckethorn area grows up to $1642.83 \mathrm{~km}^{2}$, accounting for $8.34 \%$ in a total Sandstone area of 19.7 thousand $\mathrm{km}^{2}$.

All in all, seabuckethorn's seven ecological functions

Table 2. Seabuckthorn preservation area in the Sandstone Area project-implementing counties from 1999 to 2008.

\begin{tabular}{|c|c|c|c|c|c|c|c|}
\hline Year & Dalate & Dongsheng & Fugu & Hangjin & EjinHoro & Jungar & Total \\
\hline 1999 & 8.66 & 30.47 & 0 & 0 & 0.60 & 13.10 & 52.82 \\
\hline 2000 & 8.46 & 43.53 & 15.00 & 0 & 17.20 & 19.92 & 104.11 \\
\hline 2001 & 5.61 & 43.53 & 16.27 & 0 & 5.94 & 20.26 & 91.61 \\
\hline 2002 & 14.66 & 38.25 & 23.00 & 2.21 & 33.07 & 33.46 & 144.65 \\
\hline 2003 & 22.60 & 52.29 & 50.87 & 3.13 & 41.19 & 42.66 & 212.74 \\
\hline 2004 & 32.26 & 57.31 & 85.80 & 6.3 & 27.99 & 49.98 & 259.63 \\
\hline 2005 & 26.21 & 47.26 & 16.76 & 16.02 & 48.15 & 23.65 & 178.05 \\
\hline 2006 & 41.73 & 46.00 & 33.73 & 18.6 & 41.86 & 47.21 & 229.13 \\
\hline 2008 & 18.00 & 30.15 & 46.4 & 18.51 & 31.47 & 26.11 & 170.64 \\
\hline Total & 222.44 & 431.99 & 314.5 & 80.76 & 279.47 & 313.67 & 1642.83 \\
\hline
\end{tabular}


in the Sandstone Areas make the total environmental resource value. The final calculation result (calculation detail omitted here) shows that the Sandstone Area seabuckthorn's total value is 10.017 billion RMB Yuan. Please refer to Table 3 .

By the end of the project (2008), the environmental resource value-RMB 10.017 billion equals to 37.1 times of the initial investment-RMB 0.27 billion. This achievement equals to $6.9 \%$ of the six project-implementing counties' total GDP by the end of 2008, which accounts for $16.7 \%$ of their total revenue.

The seabuckthorn's environmental resource value assessment is not just numbers; some of them have obvious external economic benefits [8] and can be realized through relative national policies and taxes, such as values of soil conservation (RMB 6388 million), water conservation (RMB 102 million) and carbon-fixation and oxygen-producing (RMB 1320 million). When they are converted into real economic value, our project can get benefits through implementation. As seabuckthorn's ecological function is regarded as public property by the state, the government or local authorities should pay for the benefits. In order to internalize the external economic values, in the regions out of the Project-implementing area where the project brings benefits, ecological compensation taxes can be levied so that the seabuckthorngrowing entities can gain profit. By this way, the seabuckthorn grower as well as the administrators can keep their motivation and enthusiasm to carry out ecological project so that seabuckthorn resource can be protected. On the other hand, the past social investment can make a return through taxes on the related local authorities and enterprises who gain external economic benefits. In recent years, carbon trade has gained wide international attention; the Carbon fixation and oxygen producing value which is up to RMB 672 million can be realized through

Table 3. The estimated environmental resource value of Artificial Seabuckthorn Forest in the Sandstone Area (2008).

\begin{tabular}{|c|c|c|c|}
\hline Ecological Function & Notation & $\begin{array}{c}\text { Environmental Resource } \\
\text { Value ( } ¥ \text { billion ) }\end{array}$ & Sequence \\
\hline Soil Conservation & B1 & 6.388 & 1 \\
\hline Water conservation & B2 & 0.102 & 7 \\
\hline $\begin{array}{l}\text { Windbreak and } \\
\text { sand-fixation }\end{array}$ & B3 & 1.320 & 2 \\
\hline Biological diversity & B4 & 1.044 & 3 \\
\hline $\begin{array}{l}\text { Carbon fixation and } \\
\text { oxygen producing }\end{array}$ & B5 & 0.672 & 4 \\
\hline Environment cleaning & B6 & 0.185 & 6 \\
\hline Landscape & B7 & 0.306 & 5 \\
\hline Total & - & 10.017 & - \\
\hline
\end{tabular}

a series of transactions in the international carbon trade.

The Shanxi, Shaanxi and Inner Mongolia Sandstone Area seabuckthorn ecological project not only have immediate effect in reducing the Yellow River sediment and improving the local ecological environment, but also plays an important role in the adjustment of the local industrial structure, the transfer of rural surplus labors, the supply of raw materials for industrial enterprises, market vitality, etc. The quantitative assessment of the environmental resource value of the Project gives evidence on the monetary value.

\section{Conclusion}

In conclusion, it is proved that the artificial seabuckthorn forest benefits the local people, the whole society and the future generations in Inner Mongolia; there is a bright future in seabuckthorn or other high-effective soil and water conservation plants ecological project implementation in similar areas.

\section{REFERENCES}

[1] J. Z. Hu, "Prediction of Landscape Pattern of Soft Sandstone Area (SSA) after Seabuckthorn Planting," American Journal of Plant Science, Vol. 3, No. 1, 2012, pp. 171176. http://dx.doi.org/10.4236/ajps.2012.31020

[2] Z. Y. Ouyang, R. S. Wang and J. Z. Zhao, "Ecosystem Services and Their Economic Valuation," Chinese Journal of Applied Ecology, Vol. 10, No. 5, 1999, pp. 635640.

[3] B. Wang and Q. H. Zhen, "Economic Value Assessment of Forest Species Diversity Conservation in China Based on the Shannon-Wiener Index," Forest Research, Vol. 21, No. 2, 2008, pp. 268-274.

[4] Y. Zhang, "Assessment on Forest Biodiversity in China," Forest Economy, Vol. 3, 2001, pp. 37-42.

[5] S. B. Wang and P. J. Wang, "Assessing the Landscape Services Value with Contingent Valuation Method: A Case Study on Suzhou Brook, Shanghai City,” Journal of Fudan University (Natural Science), Vol. 42, No. 3, 2003, 463-467.

[6] R. K. Davis, "Recreation Planning as an Economic Problem,” Natural Resources Journal, Vol. 3, 1963, pp. 239-249.

[7] H. C. Shi, "Ecosystem Services Value Estimates of Minqin Oasis Based on Contingent Valuation Method," Journal of Arid Land Resources and Environment, Vol. 22, No. 7, 2008, pp. 31-36.

[8] J. Z. Zhu, X. C. Zhou and J. Z. Hu, “On the Major Ways of Sustainable Development for Engineering of Conversion from Cropland to Forest and Grassland," Journal of Beijing Forestry University (Social Sciences), Vol. 2, No. 2, 2003, pp. 36-39. 